\title{
MORPHOMETRIC STUDY OF THE NEURONS IN HUMAN HYPOGLOSSAL NERVE NUCLEUS DURING EARLY GESTATION
}

Sreeja MT'1, Vatsalaswamy P2 ${ }^{2}$ Leo Rathinaraj AS $^{3}$

Affiliations

1. PhD scholar, Dr. DY Patil Deemed University, Pune. Lecturer, Department of Anatomy, University of Hail, Saudi Arabia.

2. Director Academics / Professor [Anatomy], Dr. D.Y. Patil Medical College, Dr. D.Y. Patil Vidhyapeeth [Deemed University], Pune.

3. Lecturer - Physiotherapy, College of Applied Medical Sciences, University of Hail, Saudi Arabia.

\begin{abstract}
Hypoglossal nerve, XII cranial nerve is responsible for the motor innervation of the tongue muscles, which assists in various motor activities such as chewing, swallowing, vocalization. Thus, weakness of this nerve will lead to weakness and deviation of the tongue to one side. Clinically besides these functions it is also responsible for the most important function such as modulation of respiration and drinking behavior. Thus, a detailed study about the cell dynamics, which involves the development of neurons in the hypoglossal nerve nucleus becomes essential. 12 foetuses [Gestational age $10-24$ weeks] were included in the study. They were divided into 4 groups based on their gestational age and CRL measurements. Hypoglossal nucleus extends throughout the length of medulla oblongata in the paramedian plane. Tissues were collected from hind brain section and section of medulla. The tissues will be processed by routine histological procedure were stained with hematoxylin \& eosin and also with Holmer's Silver nitrate to study the histological details. Morphometric study covered the cell dimensions and volumes of hypoglossal neurons and its nucleus. From these data, coefficients were drawn to identify the proportion of growth between cell and nuclear volume. Morphometric analysis of hypoglossal nerve neurons in human from $10^{\text {th }}$ to $24^{\text {th }}$ gestational week concludes that the primitive migratory cells seen in the initial period and later it will become round neuroblast. In the initial 16 weeks nucleus occupied the entire volume of the cell.
\end{abstract}

Keywords: Hypoglossal nerve nucleus, Deglutition, Mastication, Morphometry, Histogenesis

\section{INTRODUCTION}

Human nervous system is a complex network of nerves which is responsible for the transmission of the message to and from the brain and spinal cord to various parts of the body. Cranial nerves emerge directly from the brain including brain stem, whereas the spinal nerves emerge from the spinal cord [Vilensky J et al 2015]. There are 12 pairs of the cranial nerve and said to be arising from the central nervous system above the spinal cord [Kandel ER, 2013]. These nerves transmit information between the brain and various parts of our body, particularly for the head and neck areas [Standring S and Borley NR, 2008]. Hypoglossal nerve, XII cranial nerve is responsible for the motor innervation of the tongue muscles. Complex motor activities such as chewing, swallowing, vocalization and respiration needs the timely and accurate usage of the tongue movements [Miller AJ, 2002]. Injury to the hypoglossal nerve will lead to weakness and deviation of the tongue to one side [Kandel ER, 2013]. Neurons of most cranial

Submitted $5^{\text {th }}$ March 2018. Published online $15^{\text {th }}$ June 2018. To cite: Sreeja MT, Vatsalaswamy P, Leo Rathinaraj AS. Morphometric study of the neurons in human hypoglossal nerve nucleus during early gestation. Anatomy Journal of Africa. 7 (2): $1274-1280$. 
nerves have one or more nuclei in the brainstem and that of hypoglossal nerve neuron nucleus is located in the medulla [Vilensky ] et al 2015]. Lower motor neurons of this nerve are located in the bulb close to the midline and under the floor of the fourth ventricle. As like any other nerve cell it has axons and dendrites and the axons leave the nucleus as a row of tiny fascicles and descends down the neck as the hypoglossal nerve near the hyoid bone; passes anteriorly and pierces through the body of the tongue to supply hypoglossus, styloglossus, genioglossus and intrinsic muscles of tongue [Burt AM, 1995]. Hypoglossal nerve is made up of only one single fascicle at the level of hyoid bone [Mackinnon SE and Dellon AL, 1995, Asaoka K et al, 1999 and Vacher C and Dauge MC, 2004].

Hypoglossal nucleus (HGN) is present in the dorsal part of the medulla oblongata, controls certain phase of breathing but still not a welldefined vital center. Studies proved that it is not only responsible for controlling the swallowing, chewing and vocalization, but also has peak activity during breathing [Roda $\mathrm{F}$ et al, 2002]. HGN has two distinct neuronal populations, in that the first predominant one is represented by the motoneurons, which is large, multipolar and rich in Nissl substance neurons whereas the second neuronal pool is formed by inhibitory inter-neurons which is small, round or oval neurons with poor rough endoplasmatic reticulum [Cooper $\mathrm{MH}, 1981$, Boone $\mathrm{T}$ and Aldes LD, 1984 and Jankowska E and Roberts WJ, 1972]. Clinically, it has been noted that the muscles of the tongue, especially genioglossus play a vital role in maintaining a patent airway during respiration. Significant function of the two types of neuronal groups in HGN has been explained in relation to the tongue control [Withington-Wray D] et al, 1988, Lowe AA, 1978 and Lowe AA, 1980]. The available experimental studies provided this current knowledge about HGN. Literature reviews revealed only few authors that too many years ago studied about the HGN especially in human [Naeye RL et al 1989, O'Kusky JR and Norman MG, 1992 and Konrat $\mathrm{G}$ et al, 1992]. Thus, to get a clear picture about the cell dynamics and its development, morphometric study of the histogenesis of hypoglossal nerve nucleus is essential.

\section{METHODOLOGY}

Ethical clearance was obtained from the Ethical Committee, MIMSR Medical College, Hospital and Research center, Latur, Maharashtra. After explaining the research procedure and its contribution, written consent was obtained from the mother of the foetuses. Foetuses from the $10^{\text {th }}$ week of gestation to $24^{\text {th }}$ week of gestation were obtained from the cases coming for medical termination of pregnancy. Totally 12 foetuses were collected after obtaining the necessary permission from the respective parents. Complete clinical history, pregnancy details especially from the mother were collected and recorded. All the mothers were having normal medical and pregnancy history without any significant pathology. These were well preserved fresh abortuses and were fixed in the formalin solution. The gestational age of the foetuses were determined as described in the Langman's
Medical Embryology textbook with the help of CRL measurement [Sadler TW, 2012] (Tab. 1). Foetuses below 10 weeks were not considered for this study as they were at a primitive stage of development. For our convenience to record the quantitative data for analysis these of recording the quantitative details, foetuses were grouped into 4 based on their gestational age. The collected foetuses were preserved in $10 \%$ of formaldehyde solution for further research. These foetuses will be further grouped into six groups depending on their gestational period as follow:

$\begin{array}{lll}\text { Group 1 } & - & 10-14 \text { weeks } \\ \text { Group 2 } & - & 15-18 \text { weeks } \\ \text { Group 3 } & - & 19-22 \text { weeks } \\ \text { Group 4 } & - & 23-28 \text { weeks }\end{array}$


Hypoglossal nucleus extends throughout the length of medulla oblongata in the paramedian plane. Complete transverse section of medulla was taken from the fetuses. The tissues were processed by routine histological procedure. A total of 24 blocks [12 right and 12 left] were used for this study. 5 serial sections were taken from each block. The slides were numbered serially with 5 sections in each slide with a gap of 5 for each section. Sections were stained with hematoxylin \& eosin and also with Holmer's Silver nitrate to study the histological details. These histological procedures were adopted from the previous research works [Kiran S, 2004 and Narasinga Rao B and Pramila Padmini M, 2009].
Transversely cut section of the neurons in medulla will be measured with stage micrometer (0.01mm Scale) \& eye piece micrometer with 100 divisions $(0.1 \mathrm{~mm}$ Scale). Average length and breadth will be taken for this study. Serial sections of nucleus will be taken in the slide for each group. Volume of each cell [Neuron] will be calculated by using formula $a b^{2} \Pi$ / $6(n=22 / 7)$, whereas ' $a$ ' is the length and ' $b$ ' is the breadth of the neuron. Average volume will be calculated and documented. Dimensions and volumes of the neurons of hypoglossal nerve will be recorded. The statistical analysis was done using the SPSS 16.0 version to find the mean value of the length, breadth and volume in both nerve cell and nucleus of hypoglossal nerve.

\section{RESULTS}

In this research, we studied the dimensions [length \& breadth] as well as the volume of the hypoglossal nerve cell and its nucleus. The coefficient between the volume of the nerve cell and its nucleus is done to find its proportion. The mean length of the cell in hypoglossal nerve is $2.8,2.8,6.5$ and 20.8 whereas the breath is 2.8 , $2.8,4.8$ and 15.2 respectively for the stage I, II, III and IV [Tab. 2]. Similarly, the mean length of the nucleus in hypoglossal nerve cell is $2.8,2.8$, 4.5 and 13.1 whereas the breath is $2.8,2.8,4.5$ and 10 respectively for the stage I, II, III and IV [Tab. 3]. The calculated cell volume is 11.498 , $11.498,78.444$ and 2517.19 against the mean nucleus volume of $11.498,11.498,47.73$ and 686.178 gives the coefficient of proportion of $1.1,1.64$ and 3.67 in the four different stages [Tab. 4].

Table 1: Mean CRL measurements with their range.

\begin{tabular}{|l|l|l|l|l|}
\hline GROUP & GESTATIONAL AGE & $\begin{array}{l}\text { No. Of Foetuses } \\
\text { studied }\end{array}$ & $\begin{array}{l}\text { Mean CRL Range [cm] } \\
\text { Measurement[cm] }\end{array}$ & CR \\
\hline I & $10-14$ weeks & 3 & 7.3 & $6.6,7.1,8.2$ \\
\hline II & $15-18$ weeks & 3 & 12 & $10,12.2,13.8$ \\
\hline III & $19-22$ weeks & 3 & 20.9 & $19,21.8,22$ \\
\hline IV & $23-28$ weeks & 3 & 26.7 & $25,27.1,28$ \\
\hline
\end{tabular}

Table 2: Cell Dimensions

\begin{tabular}{|l|l|l|l|l|l|}
\hline Name & DIMENSIONS & $\begin{array}{c}\text { GROUP - I } \\
10-14 \\
\text { weeks }\end{array}$ & $\begin{array}{c}\text { GROUP - II } \\
15-18 \\
\text { weeks }\end{array}$ & $\begin{array}{c}\text { GROUP - III } \\
19-22 \\
\text { weeks }\end{array}$ & $\begin{array}{c}\text { GROUP - IV } \\
23-28 \\
\text { weeks }\end{array}$ \\
\hline $\begin{array}{l}\text { Hypoglossal } \\
\text { Nerve } \\
\text { nucleus }\end{array}$ & Mean Length $(\mu)$ & 2.8 & 2.8 & 6.5 & 20.8 \\
\cline { 2 - 6 } & Mean Breadth $(\mu)$ & 2.8 & 2.8 & 4.8 & 15.2 \\
\cline { 2 - 6 } & Mean Volume $\left(\mu^{3}\right)$ & 11.498 & 11.498 & 78.444 & 2517.19 \\
\hline
\end{tabular}


Table 3: Nucleus Dimension

\begin{tabular}{|l|l|l|l|l|l|}
\hline Name & DIMENSIONS & $\begin{array}{c}\text { GROUP - I } \\
10-14 \\
\text { weeks }\end{array}$ & $\begin{array}{c}\text { GROUP - II } \\
15-18 \\
\text { weeks }\end{array}$ & $\begin{array}{c}\text { GROUP - III } \\
19-22 \\
\text { weeks }\end{array}$ & $\begin{array}{c}\text { GROUP - IV } \\
23-28 \\
\text { weeks }\end{array}$ \\
\hline $\begin{array}{l}\text { Hypoglossal } \\
\text { Nerve } \\
\text { nucleus }\end{array}$ & Mean Length $(\mu)$ & 2.8 & 2.8 & 4.5 & 13.1 \\
\cline { 2 - 6 } & Mean Breadth $(\mu)$ & 2.8 & 2.8 & 4.5 & 10 \\
\cline { 2 - 6 } & Mean Volume $\left(\mu^{3}\right)$ & 11.498 & 11.498 & 47.73 & 686.178 \\
\hline
\end{tabular}

Table 4: Average volume of cell, nucleus and its coefficient:

\begin{tabular}{|l|l|l|l|l|l|}
\hline Name & DIMENSIONS & $\begin{array}{c}\text { GROUP - I } \\
10-14 \\
\text { weeks }\end{array}$ & $\begin{array}{c}\text { GROUP - II } \\
15-18 \\
\text { weeks }\end{array}$ & $\begin{array}{c}\text { GROUP - III } \\
19-22 \\
\text { weeks }\end{array}$ & $\begin{array}{c}\text { GROUP - IV } \\
23-28 \\
\text { weeks }\end{array}$ \\
\hline $\begin{array}{l}\text { Hypoglossal } \\
\begin{array}{l}\text { Nerve } \\
\text { nucleus }\end{array}\end{array}$ & $\begin{array}{l}\text { Mean cell Volume } \\
\left(\mu^{3}\right)\end{array}$ & 11.498 & 11.498 & 78.444 & 2517.19 \\
\cline { 2 - 6 } & $\begin{array}{l}\text { Mean Nucleus } \\
\text { Volume }\left(\mu^{3}\right)\end{array}$ & 11.498 & 11.498 & 47.73 & 686.178 \\
\cline { 2 - 7 } & Coefficient & 1 & 1 & 1.64 & 3.67 \\
\hline
\end{tabular}

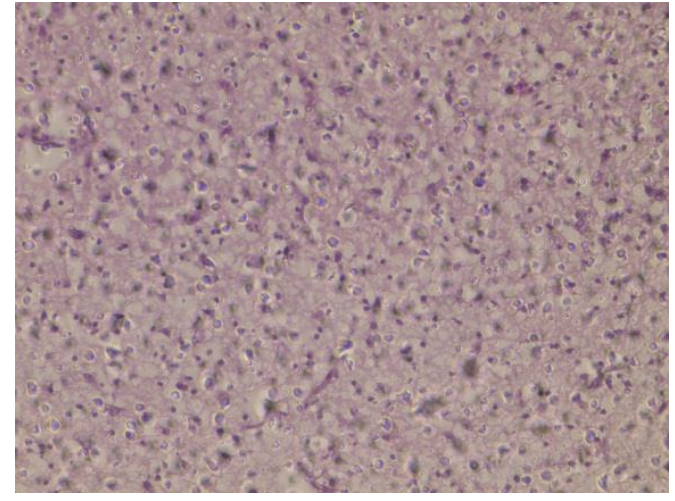

Figure 1: Shows the round neurons in the hypoglossal nerve nucleus at $14^{\text {th }}$ week of gestation. X400 Mag.

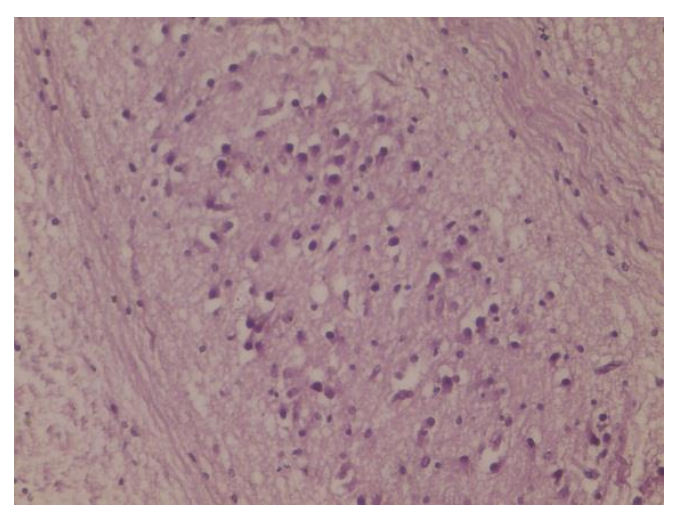

Figure 3: Neurons in the hypoglossal nerve nucleus at $20^{\text {th }}$ week gestation. X400 Mag.

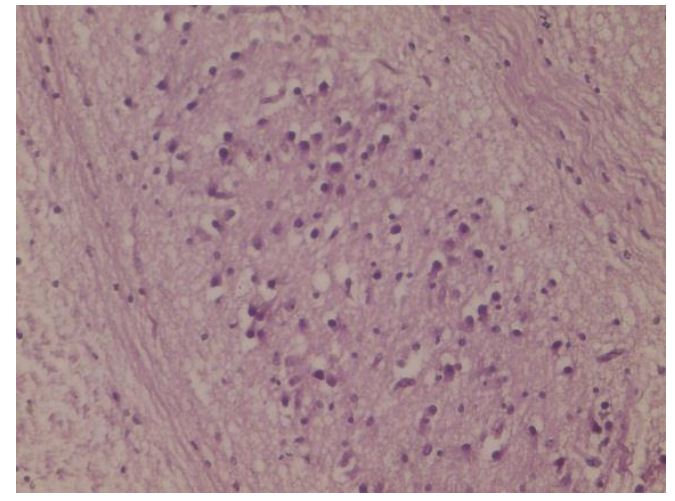

Figure 2: Round neurons in the hypoglossal nerve nucleus at $17^{\text {th }}$ week gestation. $X 400$ Mag

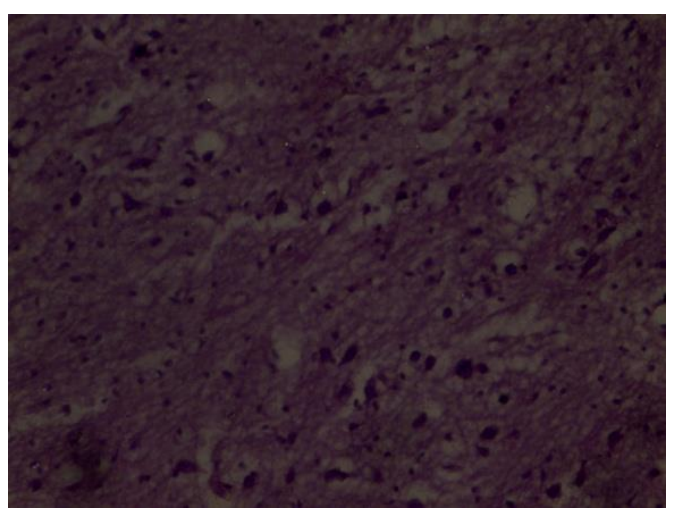

Figure 4: Neurons in the hypoglossal nerve nucleus at $26^{\text {th }}$ week gestation. X $400 \mathrm{Mag}$. 


\section{DISCUSSION}

This present study was done to have a clear picture about the morphological development of the neurons in hypoglossal nerve nucleus. The motoneurons and interneurons present in the hypoglossal nucleus are responsible for the production of excitatory and inhibitory postsynaptic potential during swallowing, chewing and breathing by the coordinated movement of the tongue. Recent evidences show that apart from these functions, tongue movement especially tongue protrusion also modulate respiration [Van Lunteren $E$ and Dick TE, 1992] and drinking behavior [Wiesenfeld $Z$ et al, 1977].

Shepard GM, 1988 studied and documented the neuronal histogenesis of central nervous system with reference to its different parts. According to him there are 7 stages of development: (1) Proliferation stage in which the cells usually generates and clones (2) Commitment to a specific type of cell such as neurons or glia (3) Migration of the cell to its final destination (4) Differentiation of the cells depending on their morphological features like axon or dendritic extensions and cytoplasmic organelle (5) Maturation of the cells by accumulation and secretion of neurotransmitter substances (6) Myelination, means acquisition of myelin sheath and (7) Apoptosis otherwise known as cell death, includes the cell which projects to abnormal target or not having enough neutrophic factor. These seven stages of neuronal histogenesis is a guide to study the development of neurons, but at the same time the exact order may differ in various parts of the nervous system.

In this study, we tried to read the appearance and maturation of the neurons in the HGN. Coefficient of proportion between the cell volume and nucleus volume of " 1 " shows that the nucleus fills the whole cell in the initial 2 groups that is in the early gestational age between 10 and 16 weeks. This is in line with the previous research work of Kiran S, 2004 in the human sympathetic ganglion neuron and that of Narasinga Rao B et al 2009 in the histogenesis of fascial nerve neuron. After 16 weeks the cell gradually increases its size in both directions thus increase in its overall volume. In group IV [22 - 24 weeks], the growth was in a high proportion of approximately 32 times [cell volume] and 14 times [nucleus volume] bigger than in group III. At the end of 24 weeks, overall growth rate of the cell is about 219 times whereas the nucleus is about 60 times compared to the earliest gestational life [10 - 12 weeks]. In the first 2 groups, the cell is accommodated completely by the nucleus [coefficient value of "1'], where as in the group III and IV it gradually grows in the proportionate rate of 1.64 and 3.67 respectively.

Clinical research studies done before with reference to the morphometric characteristic of hypoglossal nerve, identified hypoglossal-facial anastomosis is the best technique to treat peripheral facial palsy [Asaoka K et al, 1999, Vacher C and Dauge MC 2004 and Atsumi T and Miyatake T, 1987]. Altman J, 1995 reported that the neurogenesis of the hypoglossal motoneurons is completed slightly earlier than that for the facial motoneurons in rats. Similarly, in the comparative study between the facial and hypoglossal motoneuron in Brazilian opossum, Hypoglossal motoneurons have a limited migration after neurogenesis from the neuroepithelium along the fourth ventricle to the adjacent location of the HGN [Jack J. Swanson et al, 1999]. Hypoglossal motoneurons migrate to the region of the HMN prior to the growth of efferent projections.

In conclusion, this current study about the morphometry of the neurons in human hypoglossal nerve nucleus from the $10^{\text {th }}$ gestational week to the $24^{\text {th }}$ gestational week concludes that the primitive migratory cells seen in the initial stage [Group - 1] will settle down to form a round neuroblast from the second stage [Group - 2] onwards. The nucleus occupied the entire volume of the cell in the initial 16 weeks and starts growing gradually. 
Anatomy Journal of Africa. 2018. Vol 7 (2):1274 - 1280

Conflict of Interest: There is no funding agency/ research support / conflict of interest for this study.

\section{REFERENCES}

1. Altman J, Bayer SA. 1995. Neurogenesis and neuronal migration, in: G. Paxinos Ed. The Rat Nervous System, Academic Press, San Diego. p 1041-1078.

2. Asaoka K, Sawamura Y, Nagashima M, Fukushima T. 1999. Surgical anatomy for direct hypoglossal-facial nerve side-to-end "anastomosis". J Neurosurg 91: 268-75.

3. Atsumi T, Miyatake T. 1987. Morphometry of the degenerative process in the hypoglossal nerves in amyotrophic lateral sclerosis. Acta Neuropathol 73: 25-31.

4. Boone T, Aldes LD. 1984. The ultrastructure of two distinct neuron populations in the hypoglossal nucleus of the rat. Exp Brain Res 54:321-6.

5. Burt AM .1995. Neuroanatomia. Rio de Janeiro: Guanabara Koogan. p 343-4.

6. Cooper MH. 1981. The hypoglossal nucleus of the primate: a Golgi study. Neurosci Lett 21:249-54.

7. Jack J. Swanson, M. Cathleen Kuehl-Kovarik, Joel K. Elmquist, Donald S. Sakaguchi, Carol D. Jacobson. 1999. Development of the facial and hypoglossal motor nuclei in the neonatal Brazilian opossum brain. Developmental Brain Research 112:159-172.

8. Jankowska E, Roberts WJ. 1972. Synaptic actions of single interneurons mediating reciprocal inhibition of motoneurones. J Physiol 222:623-42.

9. Kandel, Eric R. 2013. Principles of neural science. $5^{\text {th }}$ Ed. Appleton and Lange: McGraw Hill. $p$ 1019-1036 / 1533-1549.

10. Kiran S. 2004. Histogenesis of Neurons in Human Sympathetic Ganglia - A Light Microscopic Study. J.Anat. Soc. India 53 (2): $148-150$.

11. Konrat G, Halliday G, Sullivan C, Harper C. 1992. Preliminary evidence suggesting delayed development in the hypoglossal and vagal nuclei of SIDS infants: a necropsy study. J Child Neurol 7:44-9.

12. Lowe AA. 1978. Excitatory and inhibitory input to hypoglossal motoneurones and adjacent reticular formation neurones in cat. Exp Neurol 62:30-47.

13. Lowe AA. 1980. The neural regulation of tongue movements. Prog Neurobiol 15:295-344.

14. Mackinnon SE, Dellon AL. 1995. Fascicular patterns of the hypoglossal nerve. J Reconstr Microsurg 11: 195-8.

15. Miller AJ. 2002. Oral and pharyngeal reflexes in the mammalian nervous system: their diverse range in complexity and the pivotal role of the tongue. Crit Rev Oral Biol Med. 13:409-425.

16. Naeye RL, Olsson JM, Combs JW. 1989. New brainstem and bone marrow abnormalities in victims of sudden infant death syndrome. J Perinatol. 9:180-3.

17. Narasinga Rao. B., Pramila Padmini. M. 2009. Histogenesis of Neurons in the nucleus of facial nerve - A study in foetuses. J. Anat. Soc. India. 58 (2): 135-139.

18. O'Kusky JR, Norman MG. 1992. Sudden infant death syndrome: postnatal changes in the numerical density and total number of neurons in the hypoglossal nucleus. J Neuro-pathol Exp Neurol. 51:577-84.

19. Roda F, Gestreau C, Bianchi AL. 2002. Discharge patterns of hypoglossal motoneurons during effective breathing, coughing and swallowing. J Neurophysiol 87:1703-11.

20. Sadler TW. 2012. Langman's Medical Embryology. $12^{\text {th }}$ Edition. Lippincot Williams \& Wilkins. p $313-15$.

21. Shepherd GM. 1988: Neurobiology. $2^{\text {nd }}$ Ed. Oxford University press, New York. p 177- 190. 
22. Standring, Susan; Borley, Neil R. 2008. "Overview of cranial nerves and cranial nerve nuclei". Gray's anatomy: the anatomical basis of clinical practice. 40 ${ }^{\text {th }}$ Ed. [Edinburgh]: Churchill Livingstone - Elsevier. p 197 - 199.

23. Vacher C, Dauge MC. 2004. Morphometric study of the cervical course of the hypoglossal nerve and its application to hypoglossal facial anastomosis. Surg Radiol Anat 26: 86-90.

24. Van Lunteren E. and Dick T. E. 1992. Breath-to-breath variability in hypoglossal motor unit firing. Resp. Physiol. 89:37-46.

25. Vilensky, Joel; Robertson, Wendy; Suarez-Quian, Carlos. 2015. The Clinical Anatomy of the Cranial Nerves: The Nerves of "On Olympus Towering Top". Ames, Iowa: Wiley-Blackwell. p $224-226$.

26. Wiesenfeld Z., Halpern B. P. and Tapper D. N. 1977. Licking behavior: Evidence of hypoglossal oscillator. Science 196: 1122-1124.

27. Withington-Wray DJ, Mifflin SW, Spyer KM. 1988. Intracellular analysis of respiratorymodulated hypoglossal motoneurons in the cat. Neuroscience 25:1041-51. 